\title{
PENGARUH WORD OF MOUTH MARKETING TERHADAP CITRA PERGURUAN TINGGI DAN DAMPAKNYA TERHADAP KEPUTUSAN MENJADI MAHASISWA DI STKIP PASUNDAN CIMAHI
}

\author{
Indah Nur Agustiani ${ }^{1}$ \\ STIEPAR YAPARI, Bandung \\ Indahmuchtar19@yahoo.com \\ Rieke Sri Rizki Asti Karini ${ }^{2}$ \\ STIEPAR YAPARI, Bandung \\ rsrak17@yahoo.com
}

\begin{abstract}
ABSTRAK
Pendidikan telah mengalami perubahan dalam era globalisasi. Berbagai strategi ditempuh di bidang ini untuk dapat memenangkan persaingan, salah satunya adalah PTS STKIP pasundan cimahi dimana ikut bersaing dalam industri pendidikan, persaingan dalam bisnis pendidikan dalam menjaring mahasiswa baru sangatlah ketat. STKIP pasundan cimahi dalam meningkatkan mahasiswanya juga diperlukan citra yang baik karena diharapkan dapat menghasilkan sesuatu kualitas yang tinggi dan sesuai atas permintaan konsumen. Maka dari itu salah satu upaya untuk meningkatkan keputusan menjadi mahasiswa di STKIP pasundan cimahi adalah dengan memaksimalkan word of mouth marketing terhadap citra perguruan tinggi di STKIP Pasundan Cimahi. Jenis penelitian yang digunakan adalah deskriptif dan verifikatif, dan metode yang digunakan adalah explanatory survey dengan teknik sampling simple random sampling, maka diperoleh jumlah sampel sebesar 100 responden. Teknik analisis data dan uji hipotesis yang digunakan adalah path analyisis (analsis jalur).

Hasil penelitian menunjukan pengaruh Pengaruh Word of Mouth Marketing berpengaruh positif dan signifikan terhadap citra perguruan tinggi. Pengaruh Word of Mouth Marketing berpengaruh positif dan signifikan terhadap keputusan menjadi mahasiswa. Pengaruh citra perguruan tinggi berpengaruh positif dan signifikan terhadap keputusan menjadi mahasiswa. Adapun saran-saran untuk perguruan tinggi dalam meningkatkan keputusan menjadi mahasiswa di STKIP pasundan cimahi adalah melalui pengembangan word of mouth marketing yang lebih menarik, kreatif, inovasi, efektif dan efisien.
\end{abstract}

Kata Kunci: Word of Mouth Marketing, Citra Perguruan Tinggi, Keputusan Menjadi Mahasiswa. 


\title{
THE INFLUENCE OF WORD OF MOUTH MARKETING ON HIGHER EDUCATION IMAGE AND ITS IMPACT ON DECISIONS TO BE STUDENTS
}

\begin{abstract}
Education has become a shaper of culture and civilization. Education in various parts of the world experiencing a fundamental change in the era of globalization. Various strategies can be adopted by business people in this field to be able to win the competition, one of which is the PTS STKIP Pasundan which compete in the education industry, competition in business education in recruiting new students are stringent. STKIP Pasundan cimahi in improving students also needed a good image because it is expected to produce something of high quality and appropriate at the request of the consumer. Thus one way to improve a student's decision in STKIP Pasundan cimahi is to maximize word of mouth marketing to the college's image in STKIP Pasundan Cimahi. This type of research is descriptive and verification, and the method used is explanatory survey simple random sampling, hence obtained a population of 100 respondent. The data analysis technique and hypothesis test used is the path analysis (path analysis). The results showed the influence Effect of Word of Mouth Marketing positive and significant impact on the image of the college. Effect of Word of Mouth Marketing has positive and significant impact on a student's decision. Effect of college imagery has positive and significant impact on a student's decision. As for suggestions for colleges to improve a student's decision in STKIP pasundan cimahi is through word of mouth marketing is the development of a more exciting, creative, innovative, effective and efficient.
\end{abstract}

Keywords: word of mouth marketing, college image, student's decision.

\section{PENDAHULUAN}

Pendidikan sudah menjadi hal yang sebagai pembentuk budaya dan peradaban manusia. Pendidikan di berbagai belahan dunia mengalami perubahan mendasar dalam era globalisasi. Pengetahuan dan keterampilan semakin dibutuhkan tidak hanya untuk memecahkan berbagai masalah yang semakin rumit, tetapi untuk mengantisipasi masalah yang akan datang sekaligus membangun masa depan yang lebih baik.

Pendidikan merupakan faktor utama dalam pembentukan pribadi manusia untuk ke depannya, pendidikan sangat berperan dalam membentuk baik atau buruknya pribadi manusia menurut ukuran normatif.

Sekolah Tinggi Keguruan dan Ilmu Pendidikan (STKIP) Pasundan merupakan salah satu perguruan tinggi swasta di wilayah Cimahi, dalam sekolah tinggi ini terdiri dari 3 (tiga) jurusan yaitu; Bahasa Inggris, Pkn dan Pendidikan Jasmani. Selain persaingan dengan PTN, dalam upayanya memperoleh mahasiswa, 
STKIP Pasundan juga harus menghadapi kompetitor yang serupa, yakni yang bergerak di bidang pendidikan juga. Berikut data mahasiswa yang mendaftar ke STKIP Pasundan Cimahi.

Tabel 1.1

\section{Mahasiswa Stkip Pasundan Cimahi Tahun 2014-2016}

\begin{tabular}{|c|c|c|}
\hline TAHUN & PRODI & JUMLAH \\
\hline 2014 & $\begin{array}{l}\text { PPKN } \\
\text { PJKR } \\
\text { B.INGGRIS }\end{array}$ & $\begin{array}{l}42 \\
363 \\
76\end{array}$ \\
\hline & Total & 481 \\
\hline 2015 & $\begin{array}{l}\text { PPKN } \\
\text { PJKR } \\
\text { B.INGGRIS }\end{array}$ & $\begin{array}{l}39 \\
384 \\
77\end{array}$ \\
\hline & Total & 500 \\
\hline \multirow[t]{2}{*}{2016} & $\begin{array}{l}\text { PPKN } \\
\text { PJKR } \\
\text { B.INGGRIS }\end{array}$ & $\begin{array}{l}59 \\
462 \\
68\end{array}$ \\
\hline & Total & 589 \\
\hline
\end{tabular}

Sumber : Manajeman STKIP 2017

Tabel 1.1 menunjukkan bahwa mahasiswa STKIP Pasundan Cimahi mengalami pertumbuhan dari tahun 2014 - 2016 tetapi tidak dapat memenuhi target yang ditetapkan oleh STKIP Pasundan Cimahi yaitu 600 mahasiswa, hal ini tentu jadi masalah yang dialami oleh STKIP Pasundan Cimahi. Oleh karena itu, dibutuhkan sebuah penelitian yang membahas mengenai permasalahan yang dialami oleh STKIP Pasundan Cimahi ini.

Berdasarkan latar belakang tersebut maka dirasakan perlu untuk mengadakan penelitian tentang "Pengaruh Word Of Mouth Marketing Terhadap Citra Perguruan Tinggi dan Dampaknya Terhadap Keputusan Menjadi Mahasiswa di STKIP Pasundan Cimahi. Berdasarkan latar belakang penelitian di atas, maka dapat dirumuskan masalah penelitian sebagai berikut:

1. Bagaimana word of mouth marketing di STKIP Pasundan Cimahi.

2. Bagaimana citra perguruan tinggi di STKIP Pasundan Cimahi.

3. Bagaimana keputusan menjadi mahasiswa di STKIP Pasundan Cimahi.

4. Seberapa besar pengaruh word of mouth marketing terhadap citra perguruan tinggi di STKIP Pasundan Cimahi

5. Seberapa besar pengaruh word of mouth marketing terhadap keputusan men jadi mahasiswa di STKIP Pasundan Cimahi.

6. Seberapa besar pengaruh citra perguruan tinggi terhadap keputusan menjadi mahasiswa di STKIP Pasundan Cimahi.

\section{Kerangka Pemikiran}

Pemasaran adalah proses menciptakan, mengkomunikasikan dan memberikan nilai kepada pelanggan serta membangun hubungan yang kuat dengan pelanggan agar dapat memberikan keuntungan. Menurut American Marketing Association dalam Kotler dan Keller (2012:5) mendefinisikan pemasaran sebagai berikut. Marketing is the activity set of institution, an prosses 
of creating, communicating, delivering, and exchanging offerings that have values for customers, clients, partners, and society at large.

Kotler dan Keller (2012:6) menyatakan bahwa orang-orang pemasaran (pemasar) memasarkan 10 tipe entitas, yakni barang, jasa, acara, pengalaman, orang, tempat, properti (hak kepemilikan), organisasi, informasi, dan ide. Akan tetapi secara garis besar, dua hal yang paling dominan dalam kegiatan pemasaran adalah pemasaran barang dan jasa. Ketika perekonomian suatu negara semakin maju maka semakin besar porsi aktivitas ekonomi yang berfokus pada produksi jasa.

Mengenai lembaga pendidikan yang termasuk ke dalam non profit organization, sedangkan istilah komersial sudah jelas berhubungan dengan kegiatan mencari laba, dengan kata lain dikomersialkan yang harus mendatangkan keuntungan bagi perguruan tinggi.

Dengan demikian, marketing jasa pendidikan berarti kegiatan lembaga pendidikan memberi pelayanan atau menyampaikan jasa pendidikan kepada konsumen dengan cara yang memuaskan (Buchari Alma 2004:45)

Kinerja pemasaran jasa dengan mengacu kepada kondisi eksternal dan pasar di antaranya adalah market share, customer loss rate, customer satisfaction, product quality, dan lain sebagainya (Kotler dan Keller, 2012:44).

Program-program pemasaran akan menggambarkan strategi yang dijalankan oleh institusi perusahaan, yang dijabarkan melalui bauran pemasaran. Menurut Kotler \& Armstrong (2008:48) begitu perusahaan telah memutuskan secara keseluruhan strategi pemasarannya, perusahaan siap untuk mulai merencanakan bauran pemasaran secara terperinci, satu dari konsep-konsep yang utama dalam pemasaran modern.

Dalam hal ini berarti bauran pemasaran jasa pendidikan adalah elemenelemen organisasi pendidikan yang dapat dikontrol oleh organisasi dalam melakukan komunikasi dengan peserta didik dan akan dipakai untuk memuaskan peserta didik. (Buchari Alma, 2004:154), elemen-elemen tersebut yakni product, price, place (or distribution), promotion (or communication), process, physical envidence and people (Buchari Alma, 2004:154), Promosi merupakan unsur bauran pemasaran jasa yang sangat penting dilaksanakan perusahaan dalam memasarkan produknya.

Menurut Kotler dan Keller $(2012: 247)$ ada 6 cara untuk melakukan komunikasi dengan calon pembeli yang dikenal dengan Promotion Mix atau bauran promosi, yaitu : Periklanan (Adevertising), Promosi Penjualan (Sales Promotion), Hubungan masyarakat dan publisitas (Public Relation), Penjualan pribadi (Personal Selling), Pemasaran langsung dan iteraktif (Direct Marceting), Rekomendasi personal (Word of Mouth) adalah komunikasi langsung antar individu, individu dengan kelompok maupun antar kelompok, untuk menyampaikan informasi produk.

Sebagian besar proses komunikasi antar manusia dilakukan melalui mulut ke mulut. Setiap hari seseorang berbicara dengan yang lainnya, saling bertukar pikiran, saling tukar informasi, saling memberikan pendapat dan proses 
komunikasi lainnya. Mungkin sebenarnya pengetahuan konsumen atas berbagai macam produk lebih banyak disebabkan adanya komunikasi dari mulut ke mulut.

Hal itu terjadi karena informasi dari teman akan lebih dapat dipercaya dibandingkan dengan informasi yang diperoleh dari iklan.

Word of mouth marketing menurut Michael .R. Solomon (2004:442) adalah "Komunikasi yang dilakukan melalui pembicaraan mulut ke mulut dengan cara menceritakan pengalaman atau keunggulan dari suatu produk. Menurut Kotler dan Keller (2012:615) word of mouth adalah komunikasi pribadi tentang suatu produk antara pembeli sasaran dan para tetangga, teman, anggota keluarga, serta rekannya. Menurut Prasetyo and Ihalauw (2005:47), word of mouth adalah komunikasi informal tentang produk atau jasa berbeda dengan komunikasi formal karena dalam komunikasi informal pengirim tidak berbicara dalam kapasitas seorang profesional atau komunikator komersial, tetapi cenderung sebagai teman.

Khasali (2011:68), mengartikan word of mouth sebagai sesuatu hal yang dibicarakan banyak orang. Pembicaraan terjadi dikarenakan ada kontroversi yang membedakan dengan hal-hal yang biasa dan normal dilihat orang. Berdasarkan definisi-definisi tersebut maka dapat dikatakan word of mouth adalah bentuk percakapan mengenai produk antara satu orang dengan orang lain tentang suatu pesan yang terkadang tidak disadari oleh pihak pengirim (sender) atau penerima (receiver) komunikasi itu sendiri.

Menurut Dony Wirawan Dahara (2008:2) : Word of mouth adalah semakin pintarnya konsumen dalam memilih informasi yang di butuhkan di bandingkan dengan iklan yang selalu menayangkan kebaikan dan keunggulan suatu produk, konsumen cenderung lebih percaya pada word of mouth karena biasanya sumber bertanya adalah orang yang bias di percaya kalau di lihat dari proses pengambilan keputusan oleh konsumen. pengaruh word of mouth marketing akan semakin besar di bandimgkan dengan iklan.

Dimensi word of mouth marketing diadopsi dari teori yang dikemukakan Kotler dan Amstrong (2011:500) dan Leary dan Shehaan. Menurut Kotler dan Amstrong (2011:500) dan Leary dan Shehaan (2008:25) berikut adalah dimensi dari word of mouth marketing.

1. Pesan

Pesan yang terdapat dalam word of mouth marketing merupakan informasi yang disampaikan kepada konsumen/calon mahasiswa (Leary dan Shehaan, 2008:25)

1. Sumber Informasi

Infomasi dalam word of mouth marketing disampaikan oleh opinion leader sebagai salah satu sumber informasi dimana seorang yang secara informal menawarkan advice atau informasi tentang suatu produk yang spesifik atau kategori produk seperti merek mana yang paling baik atau bagaimana produk tertetu digunakan (Kotler dan Keller, 2012:175) atau orang dalam reference group yang karena skill tertentu, pengetahuan, kepribadian, atau karakteristik lainnya, menggunakan pengaruh sosial kepada orang lain (Kotler dan Amstrong, 2011:163). 


\section{Hasil}

Hasil dari word of mouth marketing yang mungkin terjadi (Leary dan Shehaan, 2008:25).

Dimensi word of mouth marketing inilah yang nantinya akan mempengaruhi citra merek. Jika promosi word of mouth telah dilakukan oleh perusahaan maka seharusnya terjadi penciptaan citra merek.

Menurut Huddleston dalam (Buchari Alma, 2004:55) memberikan definisi atau pengertian citra dengan mengatakan sebagai berikut :'Image is a set beliefs the personal associate with an Image as acquired trough experience". Artinya: citra adalah serangkaian kepercayaan yang dihubungkan dengan sebuah gambaran yang dimiliki atau didapat dari pengalaman. Menurut Kotler (2012:299) definisi atau pengertian citra sebagai seperangkat keyakinan, ide, dan kesan yang dimiliki oleh seseorang terhadap suatu objek. Soleh Soemirat Soleh Soemirat dan Elvinaro (2007:113) memberikan definisi atau pengertian citra tentang bagaimana pihak lain memandang sebuah perusahaan, seseorang, suatu komite, atau suatu aktivitas.

Maka dapat diambil pengertian umum dari citra, yaitu citra merupakan hasil evaluasi dalam diri seseorang berdasarkan pengertian dan pemahaman terhadap rangsangan yang telah diolah, diorganisasikan dan disimpan dalam benak seseorang dengan tujuan untuk mengetahui secara pasti apa yang ada dalam setiap pikiran individu mengenai suatu objek, bagaimana mereka memahaminya dan apa yang mereka sukai atau tidak sukai dari objek tersebut.

Suatu citra dapat berjalan stabil dari waktu ke waktu atau sebaliknya, bisa berubah dinamis, diperkaya oleh jutaan pengalaman dan berbagai jalan pikiran asosiatif, setiap orang bisa melihat citra suatu objek berbeda-beda tergantung pada persepsi yang ada pada dirinya mengenai objek tersebut, atau sebaliknya citra bisa diterima relatif sama pada setiap anggota masyarakat, ini yang biasa disebut opini publik. Konsep citra perguruan tinggi yang digunakan dalam penelitian ini bersumber dari konsep citra organisasi atau citra perusahaan. Berikut adalah definisi-definisi mengenai citra organisasi atau citra perusahaan. Kotler dan Armstrong (2008: 299) mengungkapkan bahwa citra perusahaan merupakan seperangkat keyakinan, ide dan kesan yang dimiliki oleh seseorang terhadap suatu perusahaan. Zeithaml dan Bitner (2013:114) mengemukakan bahwa organizational image as a perception of an organization reflected in association held in consumer memory.

Menurut Keller (2012:124) dimensi citra perusahaan dari empat asosiasi penting, yaitu sebagai berikut.

1. Common Product, Attributes, Benefists or Attitudes

Nama atau merek perusahaan dapat menarik pelanggan pada asosiasi yang tinggi mengenai atribut suatu produk dan inovasi-inovasi pemasaran yang dilakukan oleh pemasar.

2. People and Relationship

Citra perusahaan dapat terlihat dari karakteristik karyawannya seperti pelayanan yang diberikan kepada pelanggan.

3. Value and Programs 
Citra perusahaan dapat dilihat dari nilai-nilai dan program-program dari perusahaan yang tidak harus berhubungan dengan produk yang dijual, misalnya bentuk kepedulian sosial, kepedulian terhadap lingkungan sekitar.

4. Corporate Credibility

Citra perusahaan dapat berupa pendapat, atau pernyataan mengenai perusahaan, juga sikap percaya terhadap perusahaan yang kompeten dalam menjual produk dan menyampaikan jasanya, serta besarnya tingkat kesukaan juga ketertarikan bagi pelanggan kepada perusahaan.

Keputusan pembelian timbul karena adanya penilaian objektif atau karena dorongan emosi. Keputusan untuk bertindak adalah hasil dari serangkaian aktifitas dan rangsangan mental emosional. Proses untuk menganalisa, merasakan dan memutuskan, pada dasarnya adalah sama seperti seorang individu dalam memecahkan banyak permasalahannya. Komsumen membentuk preferensi atas merek-merek dalam kumpulan pilihan pada saat tahap evaluasi. Konsumen juga mungkin membentuk niat untuk membeli produk yang paling disukai. Keputusan konsumen untuk memodifikasi, menunda, atau menghindari suatu keputusan pembelian sangat dipengaruhi oleh resiko yang dirasakan. Berikut disajikan enam dimensi keputusan menjadi mahasiswa berdasarkan teori keputusan pembelian dan dari beberapa jurnal, (Kotler dan Keller, 2012:183) dan (Joseph Sia Kee, 2010:53), yaitu :

\section{Location}

Konsumen harus mengambil keputusan tentang dealer mana yang akan digunakan. Pilihan saluran distribusi dalam keputusan menjadi mahasiswa berkaitan dengan pilihan lokasi perguruan tinggi.

2. Academic Programmes

Konsumen dapat mengambil keputusan untuk membeli sebuah produk atau menggunakan uangnya untuk tujuan yang lain. Pilihan produk dalam keputusan pembelian dimodifikasi menjadi pilihan program dalam keputusan menjadi mahasiswa. Samisar Md Sidin, Siti Rahayu Hussin, dan Tan Ho Soon (2003:263) dalam jurnal Asian Pasific Management Review yang berjudul An Explanatory Study of Factors Influencing the College Choice Decision of Undergraduate Student in Malaysia menyatakan bahwa salah satu indikator keputusan menggunakan jasa pendidikan adalah program issues. Selain itu, Joseph Sia Kee Ming (2010: 53) dalam International Journal of Business and Social Science yang berjudul Institutional Factors Influencing Students College Choice Decision in Malaysia: A Conceptual Framework mengemukakan bahwa academis programmes merupakan indikator dalam keputusan menggunakan jasa pendidikan. Program yang ditawarkan kepada mahasiswa STKIP Pasundan Cimahi dalam hal ini adalah program studi di STKIP Pasundan Cimahi

3. Reputation

Konsumen harus memutuskan merek mana yang akan dibeli. Dalam hal ini perusahaan harus mengetahui bagaimana konsumen memilih sebuah merek. Menurut Farham Mehboob, Syed Mir Muhammad Shah, dan Niaz A Bhuto 
(2012: 562) dalam Interdiciplinary Journal of Contemporary Research in Business yang berjudul Factors Influencing Stidents Enrollment Decisions in Selection of Higher mengatakan bahwa intitute's reputation merupakan faktor dalam keputusan menggunakan jasa pendidikan. Pilihan merek menurut Kotler dan Keller dimodifikasi menjadi college reputation. STKIP Pasundan Cimahi berusaha memberikan kesan dan citra yang baik kepada konsumen. Pilihan merek dalam keputusan pembelian dimodifikasi menjadi pilihan college reputation dalam keputusan menjadi mahasiswa STKIP Pasundan Cimahi.

4. Educational Facilities

Keputusan konsumen dipengaruhi oleh fasilitas pendidikan (educational facilities) Joseph Sia Kee Ming (2010: 53) dalam International Journal of Business and Social Science yang berjudul Institutional Factors Influencing Students College Choice Decision in Malaysia: A Conceptual Framework mengemukakan bahwa educational facilities merupakan indikator dalam keputusan untuk menjadi mahasiswa di sebuah perguruan tinggi. Dalam hal ini bisa dicontohkan seperti fasilitas kelas, alat untuk menajar dan sebagainya.

5. Cost

Konsumen akan mempertimbangkan biaya pendidikan ketika memutuskan menjadi mahasiswa. Joseph Sia Kee Ming (2010: 53) dalam International Journal of Business and Social Science yang berjudul Institutional Factors Influencing Students College Choice Decision in Malaysia: A Conceptual Framework mengemukakan bahwa educational cost merupakan indikator dalam keputusan untuk menjadi mahasiswa di sebuah perguruan tinggi. Dalam hal ini berupa biaya SPP di STKIP Pasundan Cimahi.

6. Availability of financial aid

Bantuan keuangan yang dimaksud adalah bantuan yang dianggap universitas sebagai salah satu dari empat atribut yang sangat penting yang diharapkan dari lembaga pendidikan tertentu yang lebih tinggi. dimana, siswa yang menerima penghargaan bantuan keuangan lebih mungkin untuk masuk perguruan tinggi.

7. Employment Opportunities

Konsumen memutuskan untuk menjadi mahasiswa karena kesempatan kerja ketika konsumen tersebut lulus dari perguruan tinggi. Dalam hal ini berupa peluang bekerja setelah lulus dari STKIP Pasundan Cimahi.

8. Advertising

Konsumen memutuskan untuk menjadi mahasiswa karena melihat ketertarikan media advertising yang digunakan oleh STKIP Pasundan Cimahi dan bagaimana daya tariknya, dimana advertising diartikan sebagai $s$ alah satu alat promosi, biasanya digunakan untuk mengarahkan komunikasi persuasif pada pembeli sasaran dan masyarakat dimana bentuk penyajian iklan ini bersifat non-personal.

9. HEI's representatives 
Kunjungan ke sekolah tinggi dengan perwakilan penerimaan perguruan tinggi yang dinilai sebagai pengaruh yang efektif bagi calon mahasiswa. perwakilan perguruan tinggi yang dinilai sebagai faktor yang berpengaruh dalam peran sebuah studi.

10. Campus visit

Sering mengunjungi sebuah perguruan tinggi sehinggan tertarik untuk mengambil keputusan dianggap sebagai alat perekrutan terbaik di sebuah universitas.

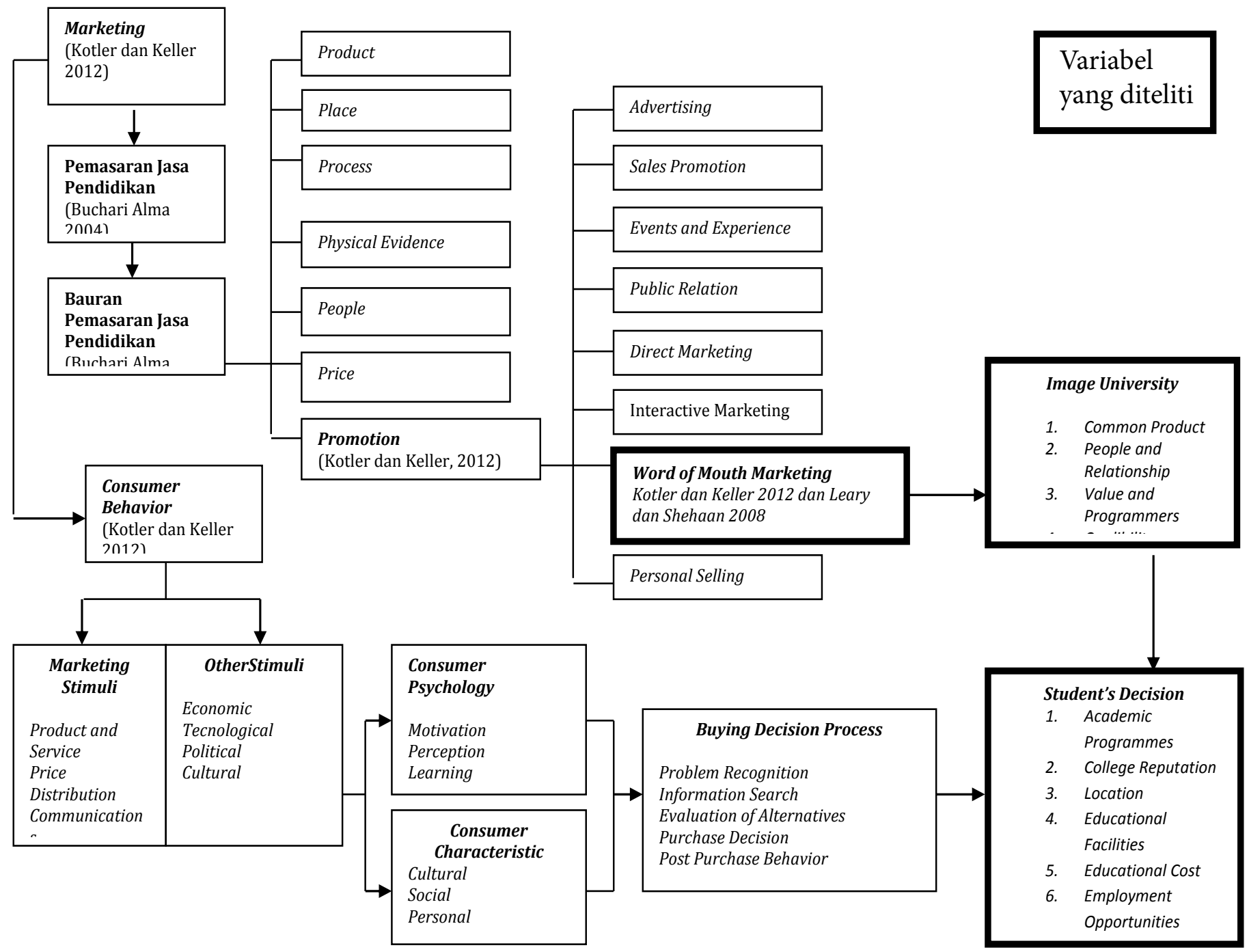

Gambar 2.1

Kerangka Pemikiran Analisis Word Of Mouth Marketing Terhadap Citra Perguruan Tinggi Serta Dampaknya Terhadap Keputusan Menjadi Mahasiswa 
Dalam kerangka pemikiran ini ada satu variabel yang akan dijadikan sebagai variabel bebas (independent) yang bersumber dari bauran pemasaran jasa terutama dalam bauran promosi, yakni word of mouth marketing, satu variabel intervening, yakni citra perguruan tinggi, sedangkan variabel terikat (dependent) ada satu yang bersumber dari teori perilaku konsumen, yakni keputusan pembelian atau dalam konteks penelitian ini adalah keputusan menjadi mahasiswa.

Pada penelitian ini keputusan pembelian menggunakan tujuh dimensi dari sepuluh dimensi keputusan pembelian. Hal tersebut dengan menghilangkan dimensi availability of financial aid, HEIs' representative, dan Campus visit karena dalam keputusan menjadi mahasiswa hal tersebut tidak dilakukan oleh STKIP Pasundan Cimahi juga tidak berlaku sehingga tidak dapat diimplementasikan. Berdasarkan kerangka penelitian, maka dapat dibuat paradigma penelitian sebagai berikut.

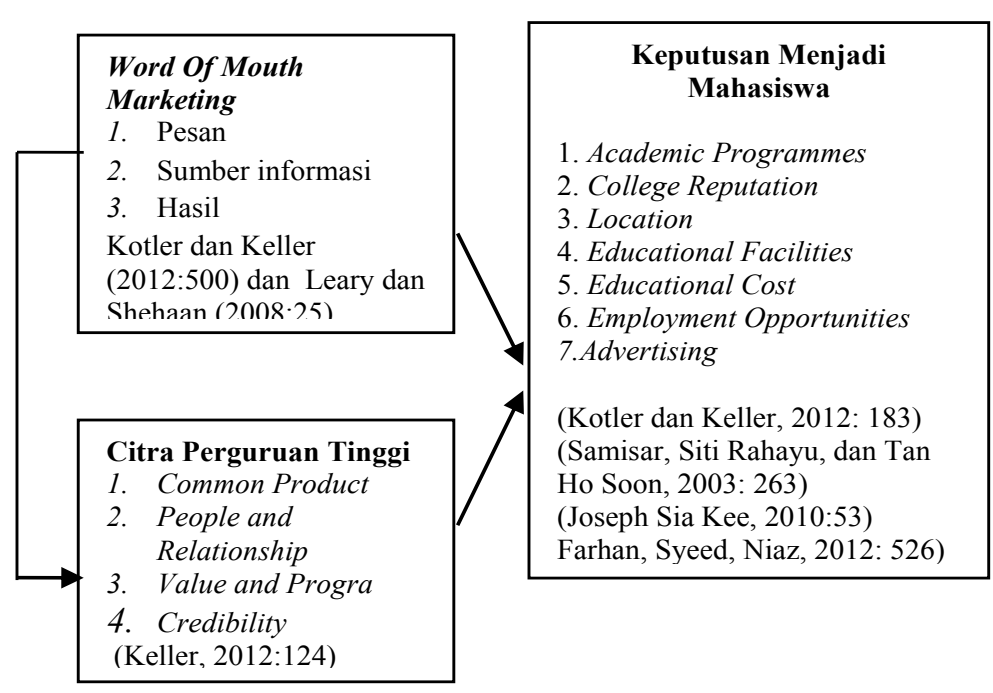

\section{Hipotesis Penelitian}

Suatu penelitian memerlukan suatu hipotesis yang merupakan jawaban sementara yang dijadikan pegangan dalam melakukan penelitian. Menurut Sugiyono (2014:64) "hipotesis merupakan jawaban sementara terhadap rumusan masalah penelitian, dimana rumusan penelitian masalah telah dinyatakan dalam bentuk kalimat". Dikatakan sementara, karena jawaban yang diberikan baru didasarkan pada teori yang relevan, belum didasarkan pada fakta-fakta empiris yang diperoleh dari pengumpulan data. Hipotesis dalam penelitian ini adalah sebagai berikut.

1. Word of mouth marketing berpengaruh terhadap citra perguruan tinggi di STKIP Pasundan Cimahi

2. Word of mouth marketing berpengaruh terhadap keputusan menjadi mahasiswa di STKIP Pasundan Cimahi.

3. Citra perguruan tinggi berpengeruh terhadap keputusan menjadi mahasiswa di STKIP Pasundan Cimahi. 


\section{METODOLOGI}

Penelitian ini terdiri atas tiga variabel yaitu variabel $\mathrm{X}, \mathrm{Y}$, dan variabel $\mathrm{Z}$. Menurut Kidder dalam Sugiyono (2014:59) variabel adalah suatu kualitas (qualities) di mana peneliti mempelajari dan menarik kesimpulan darinya. Menurut Sugiyono (2014:59), variabel independent atau variabel bebas adalah variabel yang mempengaruhi atau yang menjadi sebab berubahnya atau timbulnya variabel dependent (terikat). Variabel bebas (independent) dalam penelitian ini adalah word of mouth marketing (X).

Menurut Tuckman (dalam Sugiyono, 2014:61) menyatakan bahwa intervening variable is that factor that theoritically affect the observed phenomenon but cannot be seen. Variabel intervening adalah variabel yang secara teoretis mempengaruhi hubungan antara variabel independen dan dependen, tetapi tidak dapat diamati dan diukur. Variabel ini merupakan variabelpenyela/antara yang terletak antara variabel independen dan variabel dependen. Dalam penelitian ini, variabel interveningnya adalah citra perguruan tinggi (Y). Variabel dependen dalam penelitian ini adalah keputusan menjadi mahasiswa (Z).

Unit analisis dalam penelitian ini adalah mahasiswa yang mengambil keputusan penggunaan jasa di STKIP Pasundan Cimahi. Berdasarkan unit analisis penelitian tersebut, dianalisa mengenai promosi word of mouth marketing terhadap citra perguruan tinggi serta dampaknya kepada keputusan menjadi mahasiswa di STKIP Pasundan Cimahi.

\section{Jenis Penelitian dan Metode yang Digunakan}

Di dalam penelitian ini digunakan jenis penelitian deskriptif dan verifikatif. Berdasarkan variable-variabel yang diteliti maka jenis penelitian ini adalah penelitian deskriptif dan verifikatif.

Menurut Sugiyono (2014:35), "Penelitian deskriptif adalah penelitian yang dilakukan untuk mengetahui keberadaan variabel mandiri, baik satu variabel atau lebih variabel (variabel yang berdiri sendiri) tanpa membuat perbandingan dan atau mencari hubungan variabel satu sama lain".

Penelitian deskriptif di dalam penelitian ini bertujuan untuk memperoleh gambaran mengenai word of mouth marketing, citra perguran tinggi dan gambaran mengenai keputusan menjadi mahasiswa.

Menurut Sugiyono (2014:36), Penelitian verifikatif adalah penelitian yang membandingkan keberadaan satu variabel atau lebih pada dua atau lebih sampel yang berbeda, atau pada waktu yang berbeda. Sedangkan jenis penelitian verifikatif menguji kebenaran suatu hipotesis yang dilakukan melalui pengumpulan data di lapangan. Melalui penelitian verifikatif data-data dikumpulkan dari sumber data primer dan sekunder. Data primer diperoleh dengan menyebar kuesioner kepada sampel responden untuk memperoleh fakta yang relevan. Dalam penelitian ini di uji mengenai analisis promosi word of mouth terhadap citra perguruan tinggi serta dampaknya kepada keputusan penggunaan jasa di STKIP Pasundan Cimahi. 


\section{Operasionalisasi Variabel}

Variabel yang diteliti dalam penelitian ini dioperasionalisasikan dalam tiga variabel. Menurut Silalahi (2009:201) mengungkapkan bahwa, "Operasionalisasi variabel merupakan kegiatan mengurai variabel menjadi sejumlah variabel operasional atau variabel empiris (indikator, item) yang menunjuk langsung pada hal-hal yang dapat diamati atau diukur'. Secara lebih rinci operasionalisasi variabel dalam penelitian ini disajikan dalam Tabel 3.1 sebagai berikut.

Tabel 3.1

\section{Operasionalisasi Variabel Penelitian}

\begin{tabular}{|c|c|c|c|c|c|c|}
\hline Variabel & Sub Variabel & $\begin{array}{l}\text { Konsep } \\
\text { Variabel dan } \\
\text { Sub Variabel } \\
\end{array}$ & Indikator & Ukuran & Skala & $\begin{array}{c}\text { No } \\
\text { Item }\end{array}$ \\
\hline (1) & $(2)$ & (3) & $(4)$ & (5) & (6) & (7) \\
\hline \multirow[t]{3}{*}{$\begin{array}{l}\text { Word of } \\
\text { Mouth (X) }\end{array}$} & \multicolumn{6}{|c|}{$\begin{array}{l}\text { Word of mouth marketing adalah semakin pintarnya konsumen dalam memilih nformasi yang di butuhkan di } \\
\text { bandingkan dengan iklan yang selalu menayangkan kebaikan dan keunggulan suatu produk, konsumen cenderung } \\
\text { lebih percaya pada word of mouth karena biasanya sumber bertanya adalah orang yang bias di percaya kalau di } \\
\text { lihat dari proses pengambilan keputusan oleh konsumen Dony Wirawan Dahara }(2008: 2)\end{array}$} \\
\hline & 1. Pesan & $\begin{array}{l}\text { Pesan } \\
\text { merupakan } \\
\text { infromasi yang } \\
\text { disampaikan } \\
\text { kepada } \\
\text { konsumen } \\
\text { (Leary dan } \\
\text { Shehaan, } \\
\text { 2008:25) }\end{array}$ & \begin{tabular}{|l}
$\begin{array}{l}\text { Kelengkapan } \\
\text { pesan yang } \\
\text { disampaikan } \\
\text { kepada calon } \\
\text { mahasiswa }\end{array}$ \\
Kejelasan pesan \\
yang disampaikan \\
kepada calon \\
mahasiswa \\
Kesesuaian pesan \\
yang disampaikan \\
dengan kenyataan \\
yang sebenarnya
\end{tabular} & $\begin{array}{l}\text { Tingkat } \\
\text { kelengkapan pesan } \\
\text { yang disampaikan } \\
\text { kepada calon } \\
\text { mahasiswa } \\
\text { Tingkat kejelasan } \\
\text { pesan yang } \\
\text { disampaikan kepada } \\
\text { calon mahasiswa } \\
\text { Tingkat kesesuaian } \\
\text { pesan yang } \\
\text { disampaikan dengan } \\
\text { kenyataan yang } \\
\text { sebenarnya }\end{array}$ & Interval & \\
\hline & $\begin{array}{l}\text { 2. Sumber } \\
\text { Informasi }\end{array}$ & $\begin{array}{l}\text { Secara informal } \\
\text { menawarkan } \\
\text { advice atau } \\
\text { informasi } \\
\text { tentang suatu } \\
\text { produk yang } \\
\text { spesifik atau } \\
\text { kategori produk } \\
\text { yang memiliki } \\
\text { skill terntentu, } \\
\text { pengetahuan, } \\
\text { kepribadian, } \\
\text { atau } \\
\text { karakteristik } \\
\end{array}$ & $\begin{array}{l}\text { Kemampuan } \\
\text { memberikan } \\
\text { informasi kepada } \\
\text { calon mahasiswa } \\
\\
\text { Pengetahuan } \\
\text { yang dimiliki pada } \\
\text { jasa pendidikan } \\
\text { yang ada di } \\
\text { perguruan tinggi }\end{array}$ & $\begin{array}{l}\text { Tingkat } \\
\text { kemampuan } \\
\text { memberikan } \\
\text { informasi kepada } \\
\text { calon mahasiswa } \\
\text { Tingkat } \\
\text { pengetahuan yang } \\
\text { dimiliki pada jasa } \\
\text { pendidikan yang ada } \\
\text { di perguruan tinggi }\end{array}$ & Interval & \\
\hline
\end{tabular}




\begin{tabular}{|c|c|c|c|c|c|c|}
\hline Variabel & Sub Variabel & $\begin{array}{c}\text { Konsep } \\
\text { Variabel dan } \\
\text { Sub Variabel } \\
\end{array}$ & Indikator & Ukuran & Skala & $\begin{array}{l}\text { No } \\
\text { Item }\end{array}$ \\
\hline (1) & (2) & $(3)$ & $(4)$ & (5) & (6) & (7) \\
\hline & & $\begin{array}{l}\text { lainnya, } \\
\text { menggunakan } \\
\text { pengaruh sosial } \\
\text { kepada orang } \\
\text { lain Kotler dan } \\
\text { Amstrong } \\
(2012: 500) .\end{array}$ & $\begin{array}{l}\text { Kepercayaan } \\
\text { kepada sumber } \\
\text { informasi }\end{array}$ & $\begin{array}{l}\text { Tingkat } \\
\text { kepercayaan kepada } \\
\text { sumber informasi }\end{array}$ & & \\
\hline & 3. Hasil & $\begin{array}{l}\text { Hasil merupakan } \\
\text { hasil dari word of } \\
\text { mouth marketing } \\
\text { yang mungkin } \\
\text { terjadi } \\
\text { konsumen } \\
\text { (Leary dan } \\
\text { Shehaan, } \\
\text { 2008:25). }\end{array}$ & $\begin{array}{l}\text { Keinginan } \\
\text { menjadi } \\
\text { mahasiswa } \\
\text { setelah } \\
\text { mendapatkan } \\
\text { informasi tentang } \\
\text { STKIP Pasundan } \\
\text { Cimahi } \\
\\
\text { Keinginan } \\
\text { mencari } \\
\text { kebenaran } \\
\text { informasi yang } \\
\text { telah diterima } \\
\text { tentan STKIP } \\
\text { Pasundan Cimahi } \\
\\
\text { Keinginan } \\
\text { memberikan } \\
\text { sumber informasi } \\
\text { tentang STKIP } \\
\text { Pasundan Cimahi } \\
\text { kepada orang lain }\end{array}$ & $\begin{array}{l}\text { Tingkat keinginan } \\
\text { menjadi mahasiswa } \\
\text { setelah } \\
\text { mendapatkan } \\
\text { informasi tentang } \\
\text { STKIP Pasundan } \\
\text { Cimahi } \\
\text { Tingkat keinginan } \\
\text { mencari kebenaran } \\
\text { informasi yang telah } \\
\text { diterima tentan } \\
\text { STKIP Pasundan } \\
\text { Cimahi } \\
\text { Tingkat keinginan } \\
\text { memberikan sumber } \\
\text { informasi tentang } \\
\text { STKIP Pasundan } \\
\text { Cimahi kepada } \\
\text { orang lain }\end{array}$ & Interval & \\
\hline \multirow{3}{*}{$\begin{array}{l}\text { Citra } \\
\text { Perguruan } \\
\text { Tinggi (Y) } \\
\end{array}$} & \multicolumn{6}{|c|}{$\begin{array}{l}\text { Citra perusahaan merupakan seperangkat keyakinan, ide dan kesan yang dimiliki oleh seseorang terhadap } \\
\text { suatu perusahaan (Kotler dan Armstrong, 2008: 299) }\end{array}$} \\
\hline & 1. Common Product & $\begin{array}{l}\text { Nama atau merek } \\
\text { perusahaan dapat } \\
\text { menarik } \\
\text { pelanggan pada } \\
\text { asosiasi yang } \\
\text { tinggi mengenai } \\
\text { atribut suatu } \\
\text { produk dan } \\
\text { inovasi-inovasi } \\
\text { pemasaran yang } \\
\text { dilakukan oleh } \\
\text { pemasar. } \\
\text { (diadaptasi dari } \\
\text { Keller,2008124) }\end{array}$ & $\begin{array}{l}\text { Daya tarik nama } \\
\text { STKIP Pasundan } \\
\text { Cimahi } \\
\text { Daya tarik logo } \\
\text { STKIP Pasundan } \\
\text { Cimahi } \\
\text { Daya tarik tageline } \\
\text { STKIP Cimahi }\end{array}$ & $\begin{array}{l}\text { Tingkat daya tarik } \\
\text { nama STKIP Pasundan } \\
\text { Cimahi } \\
\text { Tingkat daya tarik } \\
\text { logo STKIP Pasundan } \\
\text { Cimahi } \\
\text { Tinfkat daya tarik } \\
\text { tageline STKIP } \\
\text { Cimahi }\end{array}$ & Interval & \\
\hline & $\begin{array}{l}\text { 2. People and } \\
\text { Relationship }\end{array}$ & $\begin{array}{l}\text { Citra perguruan } \\
\text { tinggi dapat } \\
\text { terlihat dari }\end{array}$ & $\begin{array}{l}\text { Keramahan } \\
\text { karyawan dalam } \\
\text { memberikan }\end{array}$ & $\begin{array}{l}\text { - Tingkat keramahan } \\
\text { karyawan dalam } \\
\text { memberikan }\end{array}$ & Interval & \\
\hline
\end{tabular}




\begin{tabular}{|c|c|c|c|c|c|c|}
\hline Variabel & Sub Variabel & $\begin{array}{c}\text { Konsep } \\
\text { Variabel dan } \\
\text { Sub Variabel }\end{array}$ & Indikator & Ukuran & Skala & $\begin{array}{l}\text { No } \\
\text { Item }\end{array}$ \\
\hline \multirow{4}{*}{ (1) } & (2) & (3) & (4) & (5) & (6) & (7) \\
\hline & & $\begin{array}{l}\text { karakteristik } \\
\text { karyawannya } \\
\text { seperti pelayanan } \\
\text { yang diberikan } \\
\text { kepada } \\
\text { pelanggan. } \\
\text { (diadaptasi dari } \\
\text { Keller, 2008124) }\end{array}$ & $\begin{array}{l}\text { pelayanan di STKIP } \\
\text { Pasundan Cimahi } \\
\text { - Kecepatan } \\
\text { karyawan dalam } \\
\text { memberikan } \\
\text { pelayanan di STKIP } \\
\text { Pasundan Cimahi. } \\
\text { - Kualitas dosen } \\
\text { dalam memberikan } \\
\text { pengajaran di } \\
\text { STKIP Pasundan } \\
\text { Cimahi }\end{array}$ & $\begin{array}{l}\text { pelayanan di STKIP } \\
\text { Pasundan Cimahi } \\
\text { - Tingkat kecepatan } \\
\text { karyawan dalam } \\
\text { memberikan } \\
\text { pelayanan di STKIP } \\
\text { Pasundan Cimahi. } \\
\text { - Tingkat kualitas dosen } \\
\text { dalam memberikan } \\
\text { pengajaran di STKIP } \\
\text { Pasundan Cimahi }\end{array}$ & & \\
\hline & $\begin{array}{c}\text { 3. Value and } \\
\text { Programs }\end{array}$ & $\begin{array}{l}\text { Citra perguruan } \\
\text { tinggi dapat } \\
\text { dilihat dari nilai- } \\
\text { nilai dan } \\
\text { program- } \\
\text { program dari } \\
\text { perusahaan yang } \\
\text { tidak harus } \\
\text { berhubungan } \\
\text { dengan produk } \\
\text { yang dijual, } \\
\text { misalnya bentuk } \\
\text { kepedulian } \\
\text { sosial, } \\
\text { kepedulian } \\
\text { terhadap } \\
\text { lingkungan } \\
\text { sekitar. } \\
\text { (diadaptasi dari } \\
\text { Keller, 2008124) }\end{array}$ & $\begin{array}{l}\text { - Frekuensi program } \\
\text { kepedulian sosial di } \\
\text { STKIP Pasundan } \\
\text { Cimahi } \\
\text { - Daya tarik program } \\
\text { event pertandingan } \\
\text { olahraga yang } \\
\text { dilaksanakan STKIP } \\
\text { Pasundan Cimahi }\end{array}$ & $\begin{array}{l}\text { - Tingkat Frekuensi } \\
\text { program kepedulian } \\
\text { sosial di STKIP } \\
\text { Pasundan Cimahi } \\
\text { - Tingkat daya tarik } \\
\text { program event } \\
\text { pertandingan olahraga } \\
\text { yang dilaksanakan } \\
\text { STKIP Pasundan } \\
\text { Cimahi }\end{array}$ & Interal & \\
\hline & 4. Credibility & $\begin{array}{l}\text { Citra perguruan } \\
\text { tinggi dapat } \\
\text { berupa pendapat, } \\
\text { atau pernyataan } \\
\text { mengenai } \\
\text { perusahaan, juga } \\
\text { sikap percaya } \\
\text { terhadap } \\
\text { perusahaan yang } \\
\text { kompeten dalam } \\
\text { menjual produk } \\
\text { dan } \\
\text { menyampaikan } \\
\text { jasanya, serta } \\
\text { besarnya tingkat } \\
\text { kesukaan juga } \\
\text { ketertarikan bagi } \\
\text { pelanggan kepada } \\
\text { perusahaan. }\end{array}$ & $\begin{array}{l}\text { - Kepercayaan } \\
\text { terhadap STKIP } \\
\text { Pasundan Cimahi } \\
\text { karena program } \\
\text { studi fan } \\
\text { pelayanannya } \\
\text { - Ketertarikan } \\
\text { terhadap STKIP } \\
\text { Pasundan Cimahi } \\
\text { karena program } \\
\text { studi dan } \\
\text { pelayanannya }\end{array}$ & $\begin{array}{l}\text { - Tingkat kepercayaan } \\
\text { terhadap STKIP } \\
\text { Pasundan Cimahi } \\
\text { karena program studi } \\
\text { fan pelayanannya } \\
\text { - Tingkat ketertarikan } \\
\text { terhadap STKIP } \\
\text { Pasundan Cimahi } \\
\text { karena program studi } \\
\text { dan pelayanannya }\end{array}$ & Interval & \\
\hline
\end{tabular}




\begin{tabular}{|c|c|c|c|c|c|c|}
\hline Variabel & Sub Variabel & $\begin{array}{c}\text { Konsep } \\
\text { Variabel dan } \\
\text { Sub Variabel }\end{array}$ & Indikator & Ukuran & Skala & $\begin{array}{l}\text { No } \\
\text { Item }\end{array}$ \\
\hline (1) & $(2)$ & (3) & $(4)$ & (5) & (6) & (7) \\
\hline & & $\begin{array}{l}\text { (diadaptasi dari } \\
\text { Keller, 2008124) }\end{array}$ & & & & \\
\hline \multirow{4}{*}{$\begin{array}{l}\text { Keputusan } \\
\text { Menjadi } \\
\text { Mahasiswa } \\
\text { (Z) } \\
\end{array}$} & \multicolumn{6}{|c|}{$\begin{array}{l}\text { Keputusan pembelian adalah tahap dalam proses pengambilan keputusan penggunaan jasa di mana tamu } \\
\text { benar-benar memilih tempat guna penggunaan jasa (Kotler dan Keller, } 2012: 240 \text { ) }\end{array}$} \\
\hline & 1. Location & $\begin{array}{l}\text { Konsumen harus } \\
\text { mengambil } \\
\text { keputusan } \\
\text { tentang dealer } \\
\text { mana yang akan } \\
\text { digunakan. } \\
\text { Dalam tahap ini } \\
\text { konsumen harus } \\
\text { mengambil } \\
\text { keputusan } \\
\text { tentang cara } \\
\text { yang digunakan } \\
\text { untuk } \\
\text { melakukan } \\
\text { pendaftaran. }\end{array}$ & $\begin{array}{l}\text { Kestrategisan lokasi } \\
\text { STKIP Pasundan } \\
\text { Cimahi } \\
\\
\text { Kemudahan akses } \\
\text { lokasi STKIP } \\
\text { Pasundan Cimahi }\end{array}$ & $\begin{array}{l}\text { - Tingkat kestrategisan } \\
\text { lokasi STKIP } \\
\text { Pasundan Cimahi } \\
\text { - Tingkat kemudahan } \\
\text { akses lokasi STKIP } \\
\text { Pasundan Cimahi }\end{array}$ & Interval & \\
\hline & $\begin{array}{ll}\text { 2. } & \text { Academic } \\
\text { Programmes }\end{array}$ & $\begin{array}{l}\text { Konsumen dapat } \\
\text { mengambil } \\
\text { keputusan untuk } \\
\text { memilih produk } \\
\text { pendidikan yang } \\
\text { dalam konteks } \\
\text { jasa pendidikan } \\
\text { adalah academic } \\
\text { programmes }\end{array}$ & $\begin{array}{l}\text { Keragaman program } \\
\text { studi (academic } \\
\text { programmes) di } \\
\text { STKIP Pasundan } \\
\text { Cimahi } \\
\\
\text { Kemenarikan } \\
\text { program } \\
\text { studi(academic } \\
\text { programmes) di } \\
\text { STKIP Pasundan } \\
\text { Cimahi } \\
\\
\text { Kualitas program } \\
\text { program studi } \\
\text { (academic } \\
\text { programmes) di } \\
\text { STKIP Pasundan } \\
\text { Cimahi }\end{array}$ & $\begin{array}{l}\text { - Tingkat keragaman } \\
\text { program studi } \\
\text { (academic } \\
\text { programmes) di } \\
\text { STKIP Pasundan } \\
\text { Cimahi } \\
\text { - Tingkat kemenarikan } \\
\text { program } \\
\text { studi(academic } \\
\text { programmes) di } \\
\text { STKIP Pasundan } \\
\text { Cimahi } \\
\text { - Tingkat kualitas } \\
\text { program program studi } \\
\text { (academic } \\
\text { programmes) di } \\
\text { STKIP Pasundan } \\
\text { Cimahi }\end{array}$ & Interval & \\
\hline & 3. Reputation & $\begin{array}{l}\text { Pilihan merek } \\
\text { berhubungan } \\
\text { dengan reputasi } \\
\text { dan citra dari } \\
\text { sebuah lembaga } \\
\text { pendidikan yang } \\
\text { dalam koteks } \\
\text { jasa pendidikan } \\
\text { adalah college } \\
\text { reputation }\end{array}$ & \begin{tabular}{|l} 
Reputasi (college \\
reputation) STKIP \\
Pasundan Cimahi \\
\\
Popularitas STKIP \\
Pasundan Cimahi
\end{tabular} & $\begin{array}{l}\text { - Tingkat reputasi } \\
\text { (college reputation) } \\
\text { STKIP Pasundan } \\
\text { Cimahi } \\
\text { - Tingkat Popularitas } \\
\text { STKIP Pasundan } \\
\text { Cimahi }\end{array}$ & $\begin{array}{c}1 \\
\text { Inteval }\end{array}$ & \\
\hline
\end{tabular}




\begin{tabular}{|c|c|c|c|c|c|c|}
\hline Variabel & Sub Variabel & $\begin{array}{c}\text { Konsep } \\
\text { Variabel dan } \\
\text { Sub Variabel }\end{array}$ & Indikator & Ukuran & Skala & $\begin{array}{l}\text { No } \\
\text { Item }\end{array}$ \\
\hline \multirow{5}{*}{ (1) } & $(2)$ & (3) & $(4)$ & (5) & (6) & (7) \\
\hline & $\begin{array}{l}\text { 4. Educational } \\
\text { Facilities }\end{array}$ & $\begin{array}{l}\text { Keputusan } \\
\text { konsumen dalam } \\
\text { jasa pendidikan } \\
\text { salah satunya } \\
\text { adalah fasilitas } \\
\text { pendidikan }\end{array}$ & \begin{tabular}{|l} 
Kelengkapan \\
fasilitas penunjang \\
perkuliah \\
(educational \\
facilities) di STKIP \\
Pasundan Cimahi \\
\\
Kemenarikan \\
fasilitas penunjang \\
perkuliah \\
(educational \\
facilities) di STKIP \\
Pasundan Cimahi
\end{tabular} & $\begin{array}{l}\text { - Tingkat kelengkapan } \\
\text { fasilitas penunjang } \\
\text { perkuliah (educational } \\
\text { facilities) di STKIP } \\
\text { Pasundan Cimahi } \\
\\
\text { - Tingkat kemenarikan } \\
\text { fasilitas penunjang } \\
\text { perkuliah (educational } \\
\text { facilities) di STKIP } \\
\text { Pasundan Cimahi }\end{array}$ & Interval & \\
\hline & 5. Cost & $\begin{array}{l}\text { Keputusan } \\
\text { konsumen dalam } \\
\text { jasa pendidikan } \\
\text { salah satunya } \\
\text { adalah biaya } \\
\text { pendidikan }\end{array}$ & $\begin{array}{l}\text { Keterjangkauan } \\
\text { biaya SPP di STKIP } \\
\text { Pasundan Cimahi } \\
\\
\text { Kesesuaian SPP } \\
\text { dengan kualitas di } \\
\text { STKIP Pasundan } \\
\text { Cimahi }\end{array}$ & $\begin{array}{l}\text { - Tingkat } \\
\text { keterjangkauan biaya } \\
\text { SPP di STKIP } \\
\text { Pasundan Cimahi } \\
\text { - Tingkat Kesesuaian } \\
\text { SPP dengan kualitas di } \\
\text { STKIP Pasundan } \\
\text { Cimahi }\end{array}$ & Interval & \\
\hline & $\begin{array}{l}\text { 6. Employment } \\
\text { Opportunities }\end{array}$ & $\begin{array}{l}\text { Keputusan } \\
\text { konsumen dalam } \\
\text { jasa pendidikan } \\
\text { salah satunya } \\
\text { adalah } \\
\text { kesempatan } \\
\text { kerja }\end{array}$ & Daya serap lulusan & $\begin{array}{l}\text { - Tingkat daya serap } \\
\text { lulusan }\end{array}$ & Interval & \\
\hline & 7. Advertising & $\begin{array}{l}\text { Salah satu alat } \\
\text { promosi, } \\
\text { biasanya } \\
\text { digunakan untuk } \\
\text { mengarahkan } \\
\text { komunikasi } \\
\text { persuasif pada } \\
\text { pembeli sasaran } \\
\text { dan masyarakat } \\
\text { dimana bentuk } \\
\text { penyajian iklan } \\
\text { ini bersifat non- } \\
\text { personal }\end{array}$ & \begin{tabular}{|l} 
Keragaman media \\
di STKIP Pasundan \\
Cimahi \\
\\
Daya tarik iklan di \\
STKIP Pasundan \\
Cimahi
\end{tabular} & $\begin{array}{l}\text { - Tingkat keragaman } \\
\text { media di STKIP } \\
\text { Pasundan Cimahi } \\
\\
\text { Tingkat daya tarik } \\
\text { iklan di STKIP } \\
\text { Pasundan Cimahi }\end{array}$ & Interval & \\
\hline
\end{tabular}

Sumber: Hasil pengolahan data, 2017

\section{Jenis dan Sumber Data}

Sumber data dalam penelitian adalah subjek dari mana data diperoleh, Apabila penelitian menggunakan kuesioner atau wawancara, maka sumber data disebut responden, sedangkan jika penelitian menggunakan teknik observasi, maka sumber data bisa berupa benda, gerak atau proses sesuatu. 


\subsection{Metode Penarikan Sampel}

Penelitian ini tidak meneliti seluruh populasi akan tetapi diambil sampel yang representatif (mewakili). Dalam menentukan ukuran sampel (n) dan populasi (N) yang telah ditetapkan maka dalam penelitian ini menggunakan rumus sample Slovin (Umar, 2008:141) yaitu sebagai berikut:

$\mathrm{n}=$

$$
\frac{N}{1+N \mathrm{e}^{2}}
$$

Keterangan

$\mathrm{n}=$ Ukuran sampel

$\mathrm{N}=$ Ukuran populasi

$\mathrm{e}=$ Taraf kesalahan pengambilan sampel yang masih ditolerir $(e=0,1)$

Berdasarkan rumus tersebut di atas, diperoleh jumlah sampel sebagai berikut:

$$
\begin{aligned}
& \mathrm{n}=\frac{N}{1+N \mathrm{e}^{2}} \\
& \mathrm{n}=\frac{589}{1+589(0,1)^{2}} \\
& \mathrm{n}=\frac{589}{5.9}
\end{aligned}
$$

$\mathrm{n}=99,83$ dibulatkan menjadi 100

\subsection{Prosedur Pengumpulan Data}

Pengumpulan data yang dilakukan penulis menggunakan teknik sebagai berikut.:

1. Wawancara

2. Observasi

3. Studi literatur

4. Angket/kuesioner

\subsection{Hasil Pengujian Validitas dan Reliabilitas}

Sugiyono (2014:398) mengemukakan bahwa terdapat dua hal utama yang mempengaruhi kualitas hasil penelitian, yaitu kualitas instrumen penelitian dan kualitas pengumpulan data. Menurut Arikunto (2009:211) validitas adalah suatu ukuran yang menunjukkan tingkat-tingkat kevalidan atau kesahihan suatu instrumen. Pengujian validitas instrumen dilakukan untuk menjamin bahwa terdapat kesamaan antara data yang terkumpul dengan data yang sesungguhnya terjadi pada objek yang diteliti. Suatu instrumen yang valid atau sahih mempunyai validitas yang tinggi, sebaliknya instrumen yang kurang berarti memiliki validitas rendah. Rumus untuk menghitung validitas instrumen menggunakan rumus yang digunakan oleh Pearson (Arikunto. 2009:213) yang dikenal dengan rumus korelasi product moment.

$$
r_{x y}=\frac{n \sum X Y-\left(\sum X\right)\left(\sum Y\right)}{\sqrt{\left\{n \sum X^{2}-\left(\sum X\right)^{2}\right\}\left\{n \sum Y^{2}-\left(\sum Y\right)^{2}\right\}}}
$$

\section{Keterangan}

$\mathrm{r}_{\mathrm{xy}}=$ menunjukkan indeks korelasi antara dua variabel yang dikorelasikan

$\mathrm{X} \quad=$ skor yang diperoleh subjek seluruh item 
$\mathrm{Y} \quad=$ skor total

$\sum \mathrm{X}=$ jumlah skor dalam distribusi $\mathrm{X}$

$\sum \mathrm{Y}=$ jumlah skor dalam distribusi $\mathrm{Y}$

$\sum X^{2}=$ jumlah kuadrat dalam skor distribusi $\mathrm{X}$

$\sum \mathrm{Y}^{2}=$ jumlah kuadrat dalam skor distribusi $\mathrm{Y}$

$n \quad=$ jumlah responden

Saifudin Azwar (Kusnendi, 2008:96) mengemukakan bahwa untuk menentukan item mana yang memiliki validitas yang memadai, para ahli menetapkan patokan besaran koefisien korelasi item total dikoreksi sebesar 0,25 atau 0,30 sebagai batas minimal valid tidaknya sebuah item. Perhitungan validitas item instrumen dilakukan dengan bantuan program SPSS 21 for windows.

Tabel 3.2

Hasil Uji Validitas Instrumen Penelitian

\begin{tabular}{|c|c|c|c|c|}
\hline No & PERTANYAAN & $\begin{array}{c}\text { Validita } \\
\text { s }\end{array}$ & $\begin{array}{l}\text { Koefisien Korelasi } \\
\text { Item Total Dikoreksi }\end{array}$ & Ket \\
\hline \multicolumn{5}{|c|}{ Word of Mouth Marketing } \\
\hline \multicolumn{5}{|c|}{ Pesan } \\
\hline 1 & $\begin{array}{l}\text { Kelengkapan pesan yang disampaikan } \\
\text { kepada calon mahasiswa }\end{array}$ & 0,704 & 0,25 & Valid \\
\hline 2 & $\begin{array}{l}\text { Kejelasan pesan yang disampaikan } \\
\text { kepada calon mahasiswa }\end{array}$ & 0,577 & 0,25 & Valid \\
\hline 3 & $\begin{array}{l}\text { Kesesuaian pesan yang disampaikan } \\
\text { dengan kenyataan yang sebenarnya }\end{array}$ & 0,865 & 0,25 & Valid \\
\hline \multicolumn{5}{|c|}{ Sumber Informasi } \\
\hline 1 & $\begin{array}{l}\text { Kemampuan memberikan informasi } \\
\text { kepada calon mahasiswa }\end{array}$ & 0,766 & 0,25 & Valid \\
\hline 2 & $\begin{array}{l}\text { Pengetahuan yang dimiliki pada jasa } \\
\text { pendidikan yang ada di perguruan tinggi }\end{array}$ & 0,706 & 0,25 & Valid \\
\hline 3 & Kepercayaan kepada sumber informasi & 0,690 & 0,25 & Valid \\
\hline \multicolumn{5}{|l|}{ Hasil } \\
\hline 1 & $\begin{array}{l}\text { Keinginan menjadi mahasiswa setelah } \\
\text { mendapatkan informasi tentang STKIP } \\
\text { Pasundan Cimahi }\end{array}$ & 0,691 & 0,25 & Valid \\
\hline 2 & $\begin{array}{l}\text { Keinginan mencari kebenaran informasi } \\
\text { yang telah diterima tentan STKIP } \\
\text { Pasundan Cimahi }\end{array}$ & 0,580 & 0,25 & Valid \\
\hline 3 & $\begin{array}{l}\text { Keinginan memberikan sumber } \\
\text { informasi tentang STKIP Pasundan } \\
\text { Cimahi kepada orang lain }\end{array}$ & 0,876 & 0,25 & Valid \\
\hline \multicolumn{5}{|c|}{ Citra Perguruan Tinggi } \\
\hline \multicolumn{5}{|c|}{ Common Product } \\
\hline 1 & Daya tarik nama STKIP Pasundan Cimahi & 0,417 & 0,25 & Valid \\
\hline 2 & Daya tarik logo STKIP Pasundan Cimahi & 0,511 & 0,25 & Valid \\
\hline 3 & Daya tarik tageline STKIP Cimahi & 0,577 & 0,25 & Valid \\
\hline \multicolumn{5}{|c|}{ People and Relationship } \\
\hline 1 & $\begin{array}{l}\text { Keramahan karyawan dalam memberikan } \\
\text { pelayanan di STKIP Pasundan Cimahi }\end{array}$ & 0,741 & 0,25 & Valid \\
\hline 2 & $\begin{array}{l}\text { Kecepatan karyawan dalam memberikan } \\
\text { pelayanan di STKIP Pasundan Cimahi }\end{array}$ & 0,285 & 0,25 & Valid \\
\hline 3 & Kesesuaian educational background & 0,545 & 0,25 & Valid \\
\hline
\end{tabular}




\begin{tabular}{|c|c|c|c|c|}
\hline No & PERTANYAAN & $\begin{array}{c}\text { Validita } \\
\text { s }\end{array}$ & $\begin{array}{c}\text { Koefisien Korelasi } \\
\text { Item Total Dikoreksi }\end{array}$ & Ket \\
\hline & dengan jurusan yang dipilih & & & \\
\hline \multicolumn{5}{|c|}{ Value and Programs } \\
\hline 1 & $\begin{array}{l}\text { Frekuensi program kepedulian sosial di } \\
\text { STKIP Pasundan Cimahi }\end{array}$ & 0,720 & 0,25 & Valid \\
\hline 2 & $\begin{array}{l}\text { Daya tarik program event pertandingan } \\
\text { olahraga yang dilaksanakan STKIP } \\
\text { Pasundan Cimahi }\end{array}$ & 0,510 & 0,25 & Valid \\
\hline \multicolumn{5}{|c|}{ Credibility } \\
\hline 1 & $\begin{array}{l}\text { Kepercayaan terhadap STKIP Pasundan } \\
\text { Cimahi karena program studi fan } \\
\text { pelayanannya }\end{array}$ & 0,869 & 0.25 & Valid \\
\hline 2 & $\begin{array}{l}\text { Ketertarikan terhadap STKIP Pasundan } \\
\text { Cimahi karena program studi dan } \\
\text { pelayanannya }\end{array}$ & 0,739 & 0.25 & Valid \\
\hline \multicolumn{5}{|c|}{ Keputusan Menjadi Mahasiswa } \\
\hline 1 & $\begin{array}{l}\text { Kestrategisan lokasi STKIP Pasundan } \\
\text { Cimahi }\end{array}$ & 0,274 & 0.25 & Valid \\
\hline 2 & $\begin{array}{l}\text { Kemudahan akses lokasi STKIP Pasundan } \\
\text { Cimahi }\end{array}$ & 0,268 & 0.25 & Valid \\
\hline 3 & $\begin{array}{l}\text { Keragaman program studi (academic } \\
\text { programmes) di STKIP Pasundan Cimahi }\end{array}$ & 0,265 & 0.25 & Valid \\
\hline 4 & $\begin{array}{l}\text { Kemenarikan program studi(academic } \\
\text { programmes) di STKIP Pasundan Cimahi }\end{array}$ & 0,393 & 0.25 & Valid \\
\hline 5 & $\begin{array}{l}\text { Kualitas program program studi (academic } \\
\text { programmes) di STKIP Pasundan Cimahi }\end{array}$ & 0,380 & 0.25 & Valid \\
\hline 6 & $\begin{array}{l}\text { Reputasi (college reputation) STKIP } \\
\text { Pasundan Cimahi }\end{array}$ & 0,275 & 0.25 & Valid \\
\hline 7 & Popularitas STKIP Pasundan Cimahi & 0,325 & 0.25 & Valid \\
\hline 8 & $\begin{array}{l}\text { Kelengkapan fasilitas penunjang perkuliah } \\
\text { (educational facilities) di STKIP Pasundan } \\
\text { Cimahi }\end{array}$ & 0,292 & 0.25 & Valid \\
\hline 9 & $\begin{array}{l}\text { Kemenarikan fasilitas penunjang perkuliah } \\
\text { (educational facilities) di STKIP Pasundan } \\
\text { Cimahi }\end{array}$ & 0,300 & 0.25 & Valid \\
\hline 10 & $\begin{array}{l}\text { Keterjangkauan biaya SPP yang } \\
\text { ditawarkan di STKIP Pasundan Cimahi }\end{array}$ & 0,447 & 0.25 & Valid \\
\hline 11 & $\begin{array}{l}\text { Kesesuaian SPP dengan kualitas di STKIP } \\
\text { Pasundan Cimahi }\end{array}$ & 0,298 & 0.25 & Valid \\
\hline 12 & Daya serap lulusan & 0,317 & 0.25 & Valid \\
\hline 13 & $\begin{array}{l}\text { Keragaman media di STKIP Pasundan } \\
\text { Cimahi }\end{array}$ & 0,411 & 0.25 & Valid \\
\hline 14 & $\begin{array}{l}\text { Daya tarik iklan di STKIP Pasundan } \\
\text { Cimahi }\end{array}$ & 0,270 & 0.25 & Valid \\
\hline
\end{tabular}

Sumber: Hasil Pengolahan Data 2017

Tabel 3.2 menunjukkan hasil uji validitas yang dilakukan, dapat diketahui bahwa seluruh item pertanyaa dalam instrumen penelitian adalah valid. Oleh karena itu, setiap pertanyaan dalam instrumen penelitian ini menunjukkan tingkat-tingkat kevalidan atau kesahihan yang tinggi. Hal tersebut dapat diketahui berdasarkan hasil uji validitas yang memiliki nilai lebih dari korelasi item total dikoreksi sebesar 0,25 sebagai batas minimal valid tidaknya sebuah item.

Reliabilitas menunjukkan suatu pengertian bahwa suatu instrumen cukup dapat dipercaya untuk digunakan sebagai alat pengumpulan data karena instrumen tersebut sudah baik. Reliabilitas menunjukkan tingkat keterandalan tertentu (Arikunto,2009:178). Instrumen yang sudah dapat dipercaya, yang reliabel akan mengahasilkan data yang dapat dipercaya juga. Reliable artinya 
dapat dipercaya, jadi dapat diandalkan. Uji reliabilitas dilakukan untuk melihat konsistensi responden dalam menjawab semua butir pertanyaan.

Perhitungan uji reliabilitas dalam penelitian ini menggunakan program SPSS 21.

Tabel 3.3

Hasil Uji Reliabilitas Instrumen Penelitian

\begin{tabular}{|c|l|c|c|c|}
\hline No & Variabel & $\begin{array}{c}\text { Cronbach } \\
\text { 's Alpha }\end{array}$ & $\begin{array}{c}\text { Koefisien } \\
\text { Alpha } \\
\text { Cronbach }\end{array}$ & Keterangan \\
\hline 1 & $\begin{array}{l}\text { Word of } \\
\text { Mouth } \\
\text { Marketing }\end{array}$ & 0,876 & 0,800 & Reliabel \\
\hline 2 & $\begin{array}{l}\text { Citra } \\
\text { Perguruan } \\
\text { Tinggi }\end{array}$ & 0,835 & 0,800 & Reliabel \\
\hline 3 & $\begin{array}{l}\text { Keputusan } \\
\text { Menjadi } \\
\text { Mahasiswa }\end{array}$ & 0,886 & 0,800 & Reliabel \\
\hline
\end{tabular}

Sumber: Hasil Pengolahan Data 2017

Tabel 3.3 menunjukkan hasil uji reliabilitas yang telah dilakukan, dapat diketahui bahwa seluruh pertanyaan sesuai dengan variabel penelitian adalah reliabel. Reliabilitas tersebut menunjukkan instrumen cukup dipercaya untuk digunakan sebagai alat pengumpulan data karena instrumen tersebut sudah baik.

\subsection{Pengujian Hipotesis}

Sebagai langkah terakhir dari analisis data adalah pengujian hipotesis. Teknik analisis data yang digunakan dalam penelitian ini adalah metode analisis verifikatif, maka dilakukan analisis jalur (path analysis).

Penelitian ini menggunakan analisis jalur untuk menguji hipotesis penelitian. Analisis jalur adalah metode analisis data multivariat dependensi yang digunakan untuk menguji hipotesis hubungan asimetris yang dibangun atas dasar kajian teori tertentu, dengan tujuan untuk mengetahui pengaruh langsung dan tidak langsung seperangkat variabel penyebab terhadap variabel akibat yang dapat diobservasi secara langsung (Kusnendi, 2008:147).

\section{HASIL DAN PEMBAHASAN}

\section{Tanggapan Responden mengenai Word of Mouth Marketing}

Rekapitulasi tanggapan responden mengenai word of mouth terlihat dalam Tabel 4.1 yang disajikan berikut ini. 
Tabel 4.1

Rekapitulasi Tanggapan Responden Mengenai

Word Of Mouth

Marketing

\begin{tabular}{|c|l|c|c|}
\hline No & Sub Variabel & Skor & \% \\
\hline 1 & Pesan & 1129 & 0.33 \\
\hline 2 & Sumber Informasi & 1177 & 0.34 \\
\hline 3 & Hasil & 1162 & 0.33 \\
\hline \multicolumn{2}{|c|}{ Total Skor } & 3468 & 100 \\
\hline
\end{tabular}

Sumber: Pengolahan data, 2017

Berdasarkan Tabel 4.1 menunjukkan rekapitulasi tanggapan responden mengenai word of marketing. Skor atau nilai yang paling tinggi ditunjukkan oleh subvariabel sumber informasi. informasi dimana seorang yang secara informal menawarkan advice atau informasi tentang suatu produk yang spesifik atau kategori produk seperti merek mana yang paling baik atau bagaimana produk tertetu digunakan (Kotler dan Keller, 2012:175) atau orang dalam reference group yang karena skill tertentu, pengetahuan, kepribadian, atau karakteristik lainnya, menggunakan pengaruh sosial kepada orang lain (Kotler dan Amstrong, 2008:163)

Tanggapan Responden mengenai Citra Perguruan Tinggi

Rekapitulasi tanggapan responden mengenai citra perguruan tinggi terlihat dalam Tabel 4.2 yang disajikan berikut ini.

tabel 4.2

Rekapitulasi tanggapan responden mengenai citra perguruan tinggi

\begin{tabular}{|c|c|c|c|}
\hline No & Sub Variabel & Skor & $\%$ \\
\hline 1 & Common Product & 1129 & 0.30 \\
\hline 2 & $\begin{array}{l}\text { People and } \\
\text { Relationship }\end{array}$ & 1139 & 0.31 \\
\hline 3 & Value and Programs & 750 & 0.20 \\
\hline 4 & Credibility & 715 & 0.19 \\
\hline \multicolumn{2}{|r|}{ Total Skor } & 3733 & 100 \\
\hline
\end{tabular}

Sumber: Pengolahan data, 2017

Berdasarkan Tabel di atas, dapat diketahui bahwa skor tertinggi pada variabel citra perguruan tinggi adalah terdapat pada sub variabel people and relationship. Citra perguruan tinggi dapat terlihat dari karakteristik karyawannya seperti pelayanan yang diberikan kepada pelanggan (Keller, 2012:124).

\section{Tanggapan Responden mengenai Keputusan Menjadi Mahasiswa}


Rekapitulasi tanggapan responden mengenai keputusan menjadi mahasiswa STKIP Pasundan Cimahi terlihat dalam Tabel 4.3 yang disajikan berikut ini.

Tabel 4.3

Rekapitulasi Tanggapan Responden Mengenai Keputusan Menjadi Mahasiswa

\begin{tabular}{|c|l|c|c|}
\hline No & \multicolumn{1}{|c|}{ Dimensi } & Skor & \% \\
\hline 1 & Location & 771 & 0.15 \\
\hline 2 & Academic Programmes & 1116 & 0.21 \\
\hline 3 & Reputation & 753 & 0.14 \\
\hline 4 & Educational Facilities & 751 & 0.14 \\
\hline 5 & Cost & 769 & 0.14 \\
\hline 6 & Employment Opportunities & 368 & 0.07 \\
\hline 7 & Advertising & 786 & 0.15 \\
\hline \multicolumn{2}{|c|}{ Total Skor } & 5314 & 100 \\
\hline
\end{tabular}

Sumber: Pengolahan data, 2017

Berdasarkan Tabel di atas, dapat diketahui bahwa skor tertinggi pada variabel keputusan menjadi mahasiswa adalah terdapat pada sub variabel Academic Program, yaitu kemenarikan program studi di STKIP Pasundan Cimahi.

Joseph Sia Kee Ming (2010: 53) dalam International Journal of Business and Social Science yang berjudul Institutional Factors Influencing Students College Choice Decision in Malaysia: A Conceptual Framework mengemukakan bahwa academis programmes merupakan indikator dalam keputusan menggunakan jasa pendidikan. Program yang ditawarkan kepada mahasiswa STKIP Pasundan Cimahi dalam hal ini adalah program studi di STKIP Pasundan Cimahi.

\section{HASIL PENGUJIAN HIPOTESIS}

Pengaruh Word of Mouth Marketing Terhadap Citra Perguruan Tinggi di STKIP Pasundan Cimahi

\section{Tabel 4.4}

Koefisien Pengaruh Word Of Mouth Marketing Terhadap Citra Perguruan Tinggi Stkip Pasundan Cimahi

\begin{tabular}{|c|c|c|c|c|c|}
\hline Dimensi & Pengaruh & \multicolumn{2}{|c|}{ Pengaruh Tidak Langsung } & Total \\
\cline { 3 - 5 } & Langsung & $\mathrm{X}_{1}$ & $\mathrm{X}_{2}$ & $\mathrm{X}_{3}$ & Pengaruh \\
\hline $\mathrm{X}_{1}$ & 0,1376 & - & 0,0197 & 0,0445 & 0.2018 \\
\hline $\mathrm{X}_{2}$ & 0,1176 & 0,0197 & - & 0,0431 & 0.1804 \\
\hline $\mathrm{X}_{3}$ & 0,1584 & 0,0445 & 0,0431 & - & 0.2460 \\
\hline \multicolumn{6}{|c|}{ Total Pengaruh } \\
\hline
\end{tabular}

Sumber: Hasil Pengolahan Data 2017 
Besarnya koefisien pengaruh, baik langsung maupun tidak langsung serta pengaruh word of mouth marketing terhadap citra perguruan tinggi disajikan pada Tabel 4.4. Penerimaan terhadap hipotesis didukung dengan fakta bahwa word of mouth marketing memang sangat penting dalam menentukan peningkatan citra perguruan tinggi STKIP Pasundan Cimahi.

\section{Pengaruh Word of Mouth Marketing Terhadap Keputusan Menjadi Mahasiswa di STKIP Pasundan Cimahi}

\section{Tabel 4.5}

Koefisien Pengaruh Word Of Mouth Marketing Terhadap Keputusan Menjadi Mahasiswa Stkip Pasundan Cimahi

\begin{tabular}{|c|c|c|c|c|c|}
\hline Dimensi & Pengaruh & \multicolumn{3}{|c|}{ Pengaruh Tidak Langsung } & Total \\
\cline { 3 - 5 } & Langsung & $\mathrm{X}_{1}$ & $\mathrm{X}_{2}$ & $\mathrm{X}_{3}$ & Pengaruh \\
\hline $\mathrm{X}_{1}$ & 0,1568 & - & 0,0305 & 0,0407 & 0.2280 \\
\hline $\mathrm{X}_{2}$ & 0,1267 & 0,0305 & - & 0,0378 & 0.1950 \\
\hline $\mathrm{X}_{3}$ & 0,0912 & 0,0407 & 0,0376 & - & 0.1695 \\
\hline \multicolumn{6}{|c}{ Total Pengaruh } \\
\hline
\end{tabular}

Sumber: Hasil Pengolahan Data 2017

Besarnya koefisien pengaruh, baik langsung maupun tidak langsung serta pengaruh word of mouth marketing terhadap keputusan menjadi mahasiswa disajikan pada Tabel 4.5. Penerimaan terhadap hipotesis didukung dengan fakta bahwa word of mouth marketing memang sangat penting dalam menentukan peningkatan keputusan menjadi mahasiswa STKIP Pasundan Cimahi.

\section{Pengaruh Citra Perguruan Tinggi terhadap Keputusan Menjadi Mahasiswa di STKIP Pasundan Cimahi}

Tabel 4.6

Koefisien Pengaruh Citra Perguruan Tinggi Terhadap Keputusan Menjadi Mahasiswa Stkip Pasundan Cimahi

\begin{tabular}{|c|c|c|c|c|c|c|}
\hline \multirow[t]{2}{*}{ Dimensi } & \multirow{2}{*}{$\begin{array}{l}\text { Pengaruh } \\
\text { Langsung } \\
\end{array}$} & \multicolumn{4}{|c|}{ Pengaruh Tidak Langsung } & \multirow{2}{*}{$\begin{array}{c}\text { Total } \\
\text { Pengaruh } \\
\end{array}$} \\
\hline & & Y1 & $\mathrm{Y} 2$ & $\mathrm{Y} 3$ & Y4 & \\
\hline Y1 & 0,0882 & - & 0,0207 & 0,0671 & 0,0268 & 0.2028 \\
\hline $\mathrm{Y} 2$ & 0.0488 & 0,0207 & - & 0,0198 & 0,0165 & 0.1058 \\
\hline Y3 & 0,0686 & 0,0671 & 0,0198 & - & 0,0195 & 0.1750 \\
\hline Y4 & 0,0605 & 0,0268 & 0,0165 & 0,0195 & - & 0.1233 \\
\hline \multicolumn{5}{|c|}{ Total Pengaruh } & & 0.6069 \\
\hline
\end{tabular}

Sumber: Hasil Pengolahan Data 2017

Besarnya koefisien pengaruh, baik langsung maupun tidak langsung serta pengaruh citra perguruan tinggi terhadap keputusan menjadi mahasiswa disajikan pada Tabel 4.6. Penerimaan terhadap hipotesis didukung dengan fakta bahwa citra perguruan tinggi memang sangat penting dalam menentukan peningkatan keputusan menjadi mahasiswa STKIP Pasundan Cimahi. 
Jawaban terhadap masalah penelitian ini diringkas dalan tabel berikut :

Tabel 4.7

Dekomposisi Pengaruh Antar Variabel Word Of Mouth Marketing (X), Citra Perguruan Tinggi (Y), Dan Keputusan Menjadi Mahasiswa (Z)

\begin{tabular}{|c|c|c|c|}
\hline \multirow{2}{*}{$\begin{array}{c}\text { Pengaruh } \\
\text { Antar } \\
\text { Variabel }\end{array}$} & \multicolumn{3}{|c|}{ Pengaruh } \\
\hline & $\begin{array}{l}\text { Langsung } \\
\end{array}$ & $\begin{array}{c}\text { Tidak } \\
\text { Langsung }\end{array}$ & Total \\
\hline $\mathrm{XZ}$ & 0,5925 & $\begin{array}{c}(0,8262) \\
(0,6069) \\
0.5014\end{array}$ & $\begin{array}{c}0,5925+(0,8262) \\
(0,6069) \\
11,96 \%\end{array}$ \\
\hline $\mathrm{YZ}$ & 0,6069 & - & $36,83 \%$ \\
\hline $\mathrm{XY}$ & 0,6282 & - & $39,86 \%$ \\
\hline
\end{tabular}

Sumber: Hasil Pengolahan Data 2017

Pembahasan Pengaruh Word of Mouth Marketing (X) terhadap citra perguruan tinggi (Y) serta Dampaknya pada Keputusan Menjadi Mahasiswa (Z)

Berdasarkan koefisien path yang dinyatakan sebagai Standadized Coefficient atau nilai Beta pada output coeficient, terlihat bahwa pengaruh word of mouth marketing terhadap keputusan menjadi mahasiswa, dinilai positif berpengaruh sebesar $11,96 \%$. Hal ini mengindikasikan bahwa word of mouth marketing berpengaruh secara signifikan terhadap keputusan menjadi mahasiswa. Hasil ini sesuai dengan teori bahwa yang dipaparkan oleh Dony Wirawan Dahara (2008:2) : Word of mouth adalah semakin pintarnya konsumen dalam memilih informasi yang di butuhkan di bandingkan dengan iklan yang selalu menayangkan kebaikan dan keunggulan suatu produk, konsumen cenderung lebih percaya pada word of mouth karena biasanya sumber bertanya adalah orang yang bias di percaya kalau di lihat dari proses pengambilan keputusan oleh konsumen. Pengaruh word of mouth akan semakin besar di bandimgkan dengan iklan.

Analisis untuk pengaruh citra perguruan tinggi terhadap keputusan menjadi mahasiswa menunjukkan pengaruh positif yaitu sebesar 0,3683 atau 36,83\%. Hal ini mengindikasikan bahwa citra perguruan tinggi berpengaruh secara signifikan terhadap keputusan menjadi mahasiswa. Sejalan dengan yang disampaikan Sutisna (2012:83), yang menyatakan bahwa, "Citra terhadap merek berhubungan dengan sikap yang berupa keyakinan dan preferensi terhadap suatu merek. Konsumen dengan citra yang positif terhadap suatu merek, lebih memungkinkan untuk melakukan pembelian.

Dalam penelitian ini hasil analisis untuk word of mouth marketing berpengaruh positif terhadap citra perguruan tinggi menunjukan pengaruh yang positif yaitu sebesar 0,3986 atau 39,86\%. Hal ini mengindikasikan bahwa citra perguruan tinggi berpengaruh secara signifikan terhadap keputusan menjadi mahasiswa. Menurut Prasetyo and Ihalauw (2005:47), word of mouth adalah komunikasi informal tentang produk atau jasa berbeda dengan komunikasi formal karena dalam komunikasi informal pengirim tidak berbicara dalam 
kapasitas seorang profesional atau komunikator komersial, tetapi cenderung sebagai teman.

Semua yang dilakukan dalam word of mouth marketing merupakan upaya dalam memperkuat ingatan pada benak masing-masing orang tentang hal-hal yang baik. Maka dengan hal ini tujuan word of mouth marketing dapat menciptakan citra perguruan tinggi yang mempengaruhi keputusan menjadi mahasiswa. Word of mouth marketing di STKIP Pasundan Cimahi telah dilakukan, efeknya adalah meningkatnya citra perguruan tinggi di benak konsumen, khususnya mahasiswa.

\section{SIMPULAN}

Berdasarkan penelitian yang telah dilakukan dengan menggunakan path analysis baik secara deskriptif dan verifikatif antara analisis keputusan menjadi mahasiswa melalui word of mouth marketing dan citra perguruan tinggi pada STKIP Pasundan Cimahi dapat diambil kesimpulan sebagai berikut:

1. Gambaran mengenai word of mouth marketing sudah baik berdasarkan perhitungan skor ideal, berikut dapat dijelaskan di bawah ini:

a. Word of mouth marketing pada STKIP Pasundan Cimahi yang memiliki skor tertinggi adalah sumber informasi, informasi dimana seorang yang secara informal menawarkan advice atau informasi tentang suatu produk yang spesifik atau kategori produk seperti merek mana yang paling baik atau bagaimana produk tertetu digunakan (Kotler dan Keller, 2012:175) atau orang dalam reference group yang karena skill tertentu, pengetahuan, kepribadian, atau karakteristik lainnya, menggunakan pengaruh sosial kepada orang lain (Kotler dan Amstrong, 2008:163).

b. Tanggapan responden mengenai pesan mendapatkan penilaian terendah. bahwa pesan yang disampaikan kepada mahasiswa mengenai program studi dan fasilitas di STKIP Pasundan Cimahi belum memiliki kejelasan, dari segi aspek penyampaian.

2. Gambaran mengenai citra perguruan tinggi di STKIP Pasundan Cimahi sudah baik berdasarkan perhitungan skor ideal, penilaian tertinggi adalah people and relationship. Hal ini dikarenakan Citra perguruan tinggi dapat terlihat dari karakteristik karyawannya seperti pelayanan yang diberikan kepada pelanggannya. Sedangkan yang terendah adalah credibility dimana kepercayaan mengenai produk STKIP pasundan belum baik di mata mahasiswa/i.

3. Gambaran mengenai keputusan menjadi mahasiswa di STKIP pasundan cimahi sudah baik berdasarkan perhitungan skor ideal, penilaian tertinggi adalah Academic Programmes. Hal ini dikarenakan Konsumen dapat mengambil keputusan untuk memilih produk pendidikan yang dalam konteks jasa pendidikan.

4. Pengaruh Word of Mouth Marketing berpengaruh positif dan signifikan terhadap citra perguruan tinggi. 
5. Pengaruh Word of Mouth Marketing berpengaruh positif dan signifikan terhadap keputusan menjadi mahasiswa

6. Pengaruh citra perguruan tinggi berpengaruh positif dan signifikan terhadap keputusan menjadi mahasiswa.

\section{SARAN}

Konsep word of mouth marketing dan citra perguruan tinggi merupakan hal yang penting dalam suatu universitas, karena memiliki beberapa keuntungan diantaranya adalah mengurangi biaya pemasaran, memudahkan akses, menarik mahasiswa baru, mempertahankan mahasiswa, dan banyak lagi keuntungan yang bisa diperoleh melalui word of mouth marketing dan citra perguruan tinggi, dalam hal ini penulis mencoba memberikan saran seperti hal-hal berikut:

1. Hal terpenting yang harus diperhatikan oleh pihak manajemen STKIP Pasundan Cimahi adalah adanya kejelasan dalam menyampaikan pesan tentang universitas kepada mahasiswa sehingga adanya kesesuaian pesan. Hal tersebut sejalan dengan perolehan nilai yang terendah pada dimensi tanggapan mengenai pesan.

2. Hal terpenting yang harus diperhatikan oleh pihak manajemen STKIP Pasundan Cimahi adalah mengenai kualitas pelayanan pendidikan yang diberikan karyawan terhadap mahasiswa. Pendekatan secara psikologikal yang harus diterapkan serta pelayanan yang menitikberatkan pada kebutuhan mahasiswa, sehingga mahasiswa bisa memberikan kepercayaan yang lebih kepada perguruan tinggi .Hal tersebut sejalan dengan perolehan nilai yang terendah pada dimensi Credibility.

3. Universitas harus memfokuskan kepada daya serap lulusan yang setidaknya dapat langsung bekerja (employment opportunities). Seperti adanya kerjasama antara pihak universitas dengan perusahaan yang dapat mempekerjakan lulusan dari STKIP pasundan cimahi, sehingga adanya jaminan bagi mahasiswa di STKIP pasundan cimahi bisa langsung bekerja setelah lulus.

4. Keterbatasan dalam penelitian ini yaitu peneliti hanya melakukan penelitian dengan survei terhadap mahasiswa di STKIP pasundan cimahi. Sebagai bahan rekomendasi untuk peneliti selanjutnya di STKIP pasundan cimahi, para peneliti selanjutnya dapat mengangkat masalah lain seperti pengaruh harga yang ditawarkan agar keputusan menjadi mahasiswa terus meningkat sesuai dengan target sehingga STKIP pasundan cimahi akan semakin maju dan berkembang.

\section{DAFTAR PUSTAKA}

Arikunto, S. 2009. Manajemenn Penelitian. Jakarta: Rineka Cipta.

Buchari Alma. 2004. Manajemen Pemasaran dan Pemasaran Jasa. Bandung : CV Alfabeta 
Kasali, R. 2011. Membidik Pasar Indonesia: Segmentasi, Targeting, dan Positioning. Jakarta : PT Gramedia Pustaka Utama

Kotler, P. \& Amstrong, G. 2008. Principles of Marketing 11 Editithn. New Jersey: Prentice Hall.

Kotler, P. \& Kevin L. K. 2012. Marketing Management 14 Edition. ${ }^{\text {th }}$ New Jersey: Prentice Hall

Kusnendi.2008. Model-model Persamaan Struktural. Bandung: CV Alfabeta

O'Leary, S. dan Sheehan. 2008. Building Buzz to Beat the Big Boys Word of Mouth Marketing for Small Bussiness. United States of America: Praeger Publishers.

Solomon, M. R. Consumer. 2004. Behavior, Buying, Having and Being. New Jerse : Pearson Education.

Soemirat, S. \& Ardianto, E. 2007. Dasar-Dasar Public Relations. Bandung, Rosdakarya

Husein, U. 2008. Metode Penelitian untuk Skripsi dan Tesis Bisnis. Jakarta: Rajagrafindo Persada.

Ristiyanti P. dan Jhon J.I.O Ihalauw. 2005. Prilaku Konsumen. Penerbit Andi : yogyakarta.

Sugiyono. 2014. Metode Penelitian Kuantitatif Kualitatif dan R\&D. Bandung : Alfabeta

Sutisna, 2012, Perilaku Konsumen dan Komunikasi Pemasaran, Edisis kedua, Bandung: Remaja Rosdakarya.

Ulber S. 2009. Metode Penelitian Sosial, PT Refika Aditama, Bandung.

Wirawan D. D, 2008. Rangkuman WOM, http:/www.donydw.wordpress.com

Zeithaml, V.A., M.J. Bitner, D.D. Gremler. 2013. Services Marketing: Integrating Customer Focus Across the Firm6thed. Mc.Graw-Hill. Boston.

\section{Sumber Literatur Jurnal dan Website}

Yoseph Sia Kee Ming (2010). Institutional Factors Influencing Students' College Choice Decision in Malaysia : A Conseptual Framework

Zahooh Ahmad (2012). Word of Mouth Communications: A Powerful Contributor to Consumers Decision Making in Healtcare

Martin Williams, Francis Buttle, dan Sergio Biggemann (2012). Relating Word of Mouth to Corporate Reputation

www.stkippasundan.ac.id 